\title{
Socioeconomic Aspects for Coastal Mollusk Commercial Fishing in Costa Chica, Guerrero, México
}

\author{
Lizeth Galeana-Rebolledo1, Rafael Flores-Garza ${ }^{1,2}{ }^{*}$, Juan Violante-González ${ }^{1,2}$, \\ Pedro Flores-Rodríguez ${ }^{1,2}$, Sergio García-Ibáñez ${ }^{1,2}$, Victor Landa-Jaime ${ }^{3}$, \\ Arcadio Valdés-González ${ }^{4}$ \\ ${ }^{1}$ Centro de Ciencias de Desarrollo Regional, Pino s/n. Col. El Roble, Acapulco, México \\ ${ }^{2}$ Facultad Ecología Marina, Gran Vía Tropical, N²0, Fraccionamiento Las Playas, Acapulco, México \\ ${ }^{3}$ Departamento de Estudios para el Desarrollo Sustentable de Zonas Costeras, San Patricio-Melaque, \\ México \\ ${ }^{4}$ Facultad de Ciencias Biológicas, Universidad Autónoma de Nuevo León, Ciudad Universitaria, \\ San Nicolás de los Garza, México \\ Email: *rfloresgarza@yahoo.com
}

How to cite this paper: Galeana-Rebolledo, L., Flores-Garza, R., Violante-González, J., Flores-Rodríguez, P., García-Ibáñez, S., Landa-Jaime, V. and Valdés-González, A. (2018) Paper Title. Natural Resources, 9, 229-241. https://doi.org/10.4236/nr.2018.96015

Received: January 11, 2018

Accepted: June 18, 2018

Published: June 21, 2018

Copyright (c) 2018 by authors and Scientific Research Publishing Inc. This work is licensed under the Creative Commons Attribution International License (CC BY 4.0).

http://creativecommons.org/licenses/by/4.0/

\section{Open Access}

\begin{abstract}
An important part of the fishing activity in Mexico is carried out in the coastal strip and has a strong social, economic and ecological importance. In the state of Guerrero, mollusks fishing is coastal and craftwork activity focused on a small number of species and without information on biology and reproductive or ecological aspects for most species caught. This research was carried out in the Costa Chica region, Guerrero, Mexico and the aims were: 1) To analyze the socioeconomic features of cooperative societies of fishing production; and 2) To know the diversity of mollusks caught by coastal fishing and the species that have the greatest importance in fishing. From February to April 2013-2015, seven fish coop units, four piers and places where seafood is sold were visited. For the socio-economic analysis and the determination of the species that have more importance in the coastal fishing, a total of 67 surveys were applied. In order to determine the cast of species, the specimens captured by the fishermen were used, which were identified and counted. A total of 67 interviews were analyzed and an average of $\$ 1806.00$ was estimated as weekly economic income just as a product of fishing, it was also estimated that on average the fishermen work 4.3 days a week. Fisheries cooperatives market most of their produce directly to restaurateurs and locals on the piers. Replacement of older adults by young fishermen from the same region was observed, most are adults between 22 and 39 years old. 25 species of mollusks of economic importance were registered for the coastal fishermen of the Costa
\end{abstract}


Chica. Six species were identified as the main target for catching fishermen. The fishing of mollusks in Costa Chica is not subject to any type of control, which has led to overfishing reflected in the decline sizes and banks in populations of commercial importance.

\section{Keywords}

Molluscs, Coastal Fishing, Socioeconomic, Fisherman

\section{Introduction}

Fishing is one of the main activities that takes place on the coastal regions of Mexico and has social, economic and ecological importance. The resources of this activity are varied and are mainly oriented to the capture of species of greater commercial importance. A high percentage of the catch comes from coastal fisheries. [1] mentioned that coastal fishermen are those social actors whose main activity is fishing, have smaller boats, equipped with different technological development, and must disembark at their place of origin or any other coastal. The fishing groups have organized themselves into fishing cooperatives, which can contribute to responsible fishing, food security and the eradication of poverty. The success of fisher organizations is possible, feasible and desirable, because they can make an important contribution to community development. At present, coastal fishing cooperatives in Mexico do not have a positive outlook, as a result of the application of inadequate policies that have been based on external strategies delineated for circumstances and needs different from the reality of Mexico [2].

In the state of Guerrero, the problem that persists in the fishing sector is that the growth of fishing is far from being considered sustainable, in addition fishermen and their families have a high degree of poverty, adding to this is the degradation of natural resources. Most coastal fisheries resources such as molluscs are exploited without knowledge of their biology and ecology and, therefore, no measures can be taken to promote the sustainable management of the resource. In addition to the unfavorable economic environment, fishing is a natural resource that is in a phase of deterioration due to overfishing, as a consequence of unregulated catches [3].

In the state of Guerrero there is no special infrastructure for coastal fishing, there are few places on the coast that have a collection center for fishery products, many families subsist on fishing and in recent years the number of fishermen and boats has increased, due to the ease of obtaining of a permit [4]. The two most important tourist centers of the State, Acapulco and Ixtapa-Zihuatanejo, group the largest number of cooperatives, boats, divers and fishermen in addition to the concentration of the products with the greatest commercial demand, such as the rock oyster. To satisfy the demand of mollusk from these markets, mollusk must be imported from other parts of the state, such as what is caught 
in the Costa Chica region of the State of Guerrero, in addition to importing shellfish from other states of the country [5]. Mollusk fishing in Guerrero can be characterized as costal fishing, artisanal, focused on a limited number of species and without information on reproductive biology and ecology in most of the species that are captured [3]. On the other hand, the information that exists about some species of molluscs that comes from regions with different environmental conditions. Therefore it is necessary to carry out a fishery and socioeconomic diagnosis of the resources that are subject to exploitation, it is also necessary to evaluate the fishing market and if this is able to meet the future demand of molluscs for human consumption in a harmonic manner with the environment and what elements are necessary to promote and develop sustainable fishing.

The present study had as objectives 1) Analyze the socio-economic characteristics of the fisher's members of the Cooperative Society of Fishery Production (CSFP) in the Costa Chica region of the State of Guerrero; and 2) Determine the diversity of mollusks captured by costal fishing and the species that have higher importance in fishing.

\section{Field Methodology}

\subsection{Study Area}

The study was carried out in the Costa Chica region in the State of Guerrero, it is located on the east and southeast limits of the municipality of Acapulco de Juárez and extends to the coast of the State of Oaxaca. It is located between $16^{\circ} 15^{\prime}$ and $17^{\circ} 15^{\prime}$ North and $98^{\circ} 30^{\prime}$ West [6] (Figure 1).

Based on the information provided by the Ministry of Agriculture, Livestock, Rural Development, Fisheries and Food (Mexico) (in Spanish Secretaría de Agricultura, Ganadería, Desarrollo Rural, Pesca y Alimentación de México: SAGARPA), in the Costa Chica there are seven Cooperative Fishing Production Societies, which have permits for the fishing of marine mollusks (rock oyster and snail) and according to the census provided by SAGARPA, a total of 166 fishermen are affiliated with the seven fishing cooperatives.

\subsection{Field Work}

The fieldwork was carried out from February to April 2013 to 2015. To know the socio-economic characteristics of fishermen and their families, two types of the interview were carried out, one to the presidents or secretaries of the cooperatives and a different one to associates of the fish coop units.

The interview for presidents consisted of 37 open answer questions, focused on the characteristics of fishing cooperatives. The fishermen interview consisted of 28 questions in total: nine multiple choice questions and 19 open answer questions. The interview was structured into three sections: 1) General data of the fishing cooperatives, 2) Fisherman's data, and 3) Productive activity.

With the data obtained from the interviews, the main mollusc fisheries of the 


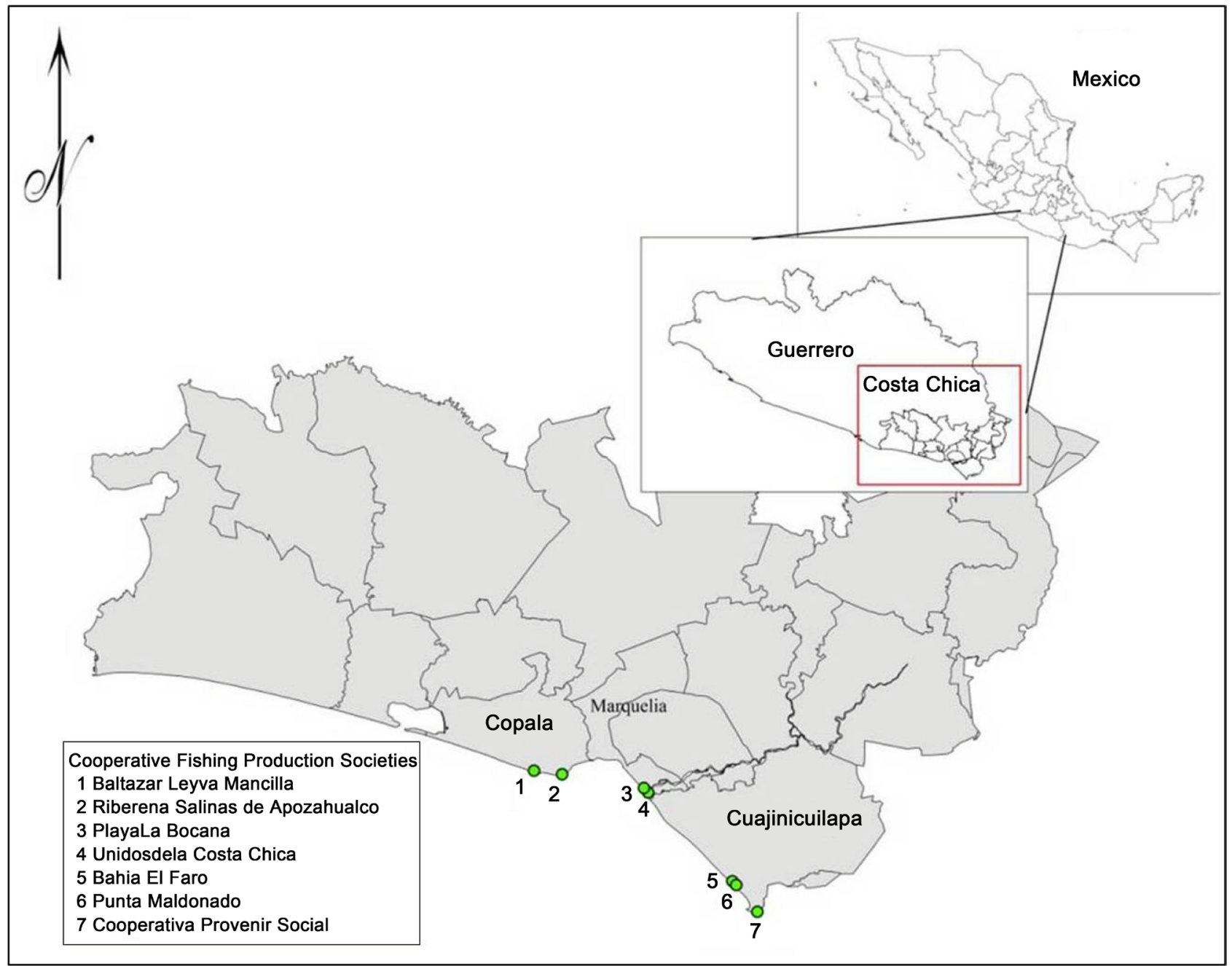

Figure 1. Location of the Costa Chica and fisheries production cooperatives.

Costa Chica region were also determined. In order to determine the list of mollusc species and the species that are most important in coastal fishing in the Costa Chica, seven fishing cooperatives were visited, as well as the landing sites and places where molluscs are sold. Authorization was requested to the fishermen and the owners of the places where molluscs are sold to examine the mollusc specimens. Only specimens that were fished in the Costa Chica region were included in the sample. The specimens were identified and quantified.

Those specimens of which there was difficulty identifying in the field were purchased. The specimens collected were preserved in $96 \%$ ethyl alcohol, and were transferred to the laboratory, where the appropriate taxonomic location and the updating of the nomenclature were carried out, using specialized literature such as [7] [8] [9] [10] and [11] and the website. Photographs of the identified species were taken and the specimens were deposited in the mollusk collection of the Facultad de Ecología Marina de la Universidad Autónoma de Guerrero. A database was developed for the analysis of interview data and the collection of specimens, descriptive statistics of the variables were estimated and the 
number of species, the number of organisms extracted per species and the amount of fishing per species were estimated, by fisherman and by each fishing production cooperative society. The information provided by the fishermen was verified in the field in visits to the landing sites and to the places where they commercialized the product of fishing and to their fishing area trips accompanied by fishermen.

\section{Results}

\subsection{Socioeconomic Characteristics of Fishermen Who Are Members of Fishery Cooperatives in the Costa Chica}

According to data provided by SAGARPA, in 2014, the officially registered register of fishermen with a permit to catch molluscs in Costa Chica was 166 people. Of these, 67 fishermen were interviewed, of which 63 were born in the Costa Chica region and 4 were born in another region of the State of Guerrero.

It was estimated that the main work activity of the interviewees was that of fishermen (97.56\%), and stated that they work secondarily as farmers with which they supplement their income to solve their needs. Only $2.44 \%$ have as their main activity that of a farmer and complemented their living needs as fishermen.

It was estimated that the main work activity of the interviewees was that of fisherman (97.56\%), and stated that they work secondarily as farmers with which they supplement their income to solve their needs. Only $2.44 \%$ have as their main activity that of a farmer and complemented their living needs as fishermen.

The average age of the interviewees was 41.7 years, the majority $(51.1 \%)$ are between 22 and 40 years old, the rest is between 41 to 59 years (38.8\%) and 60 to 74 years $(9.7 \%)$. It is observed that there is a replacement of older fishermen by young people from the same region.

In the level of education of the interviewed fishermen it was observed that $39.02 \%$ have unfinished basic education (in Mexico the basic education is of 6 years and is known as primary education) followed by those who have unfinished basic secondary education (31.71\%) (In Mexico the basic secondary education is known as secondary and full period of studies is 3 years), however it was found that $4.88 \%$ have university studies (Figure 2 ).

The experience as a diver of the interviewees is very heterogeneous, they average 18.95 years, and there are divers of recent entry to this activity and others whose diving experience is 43 years. It was recorded that $31.6 \%$ of the interviewees have experience as diver from 1 to 10 years, $34.1 \%$ from 11 to 20 years, $17.1 \%$ from 21 to 29 years, $9.7 \%$ from 30 to 40 years and $7.3 \%$ between 41 to 43 years old.

In relation to the experience they have as partners of a cooperative society of fish production, it was estimated that $68.2 \%$ of the fishermen interviewed have a maximum of 20 years of experience as a partner.

According to the interview data and fishing permits, it was found that each fisherman has the basic equipment consisting of visors, fins, float, backpacks, 


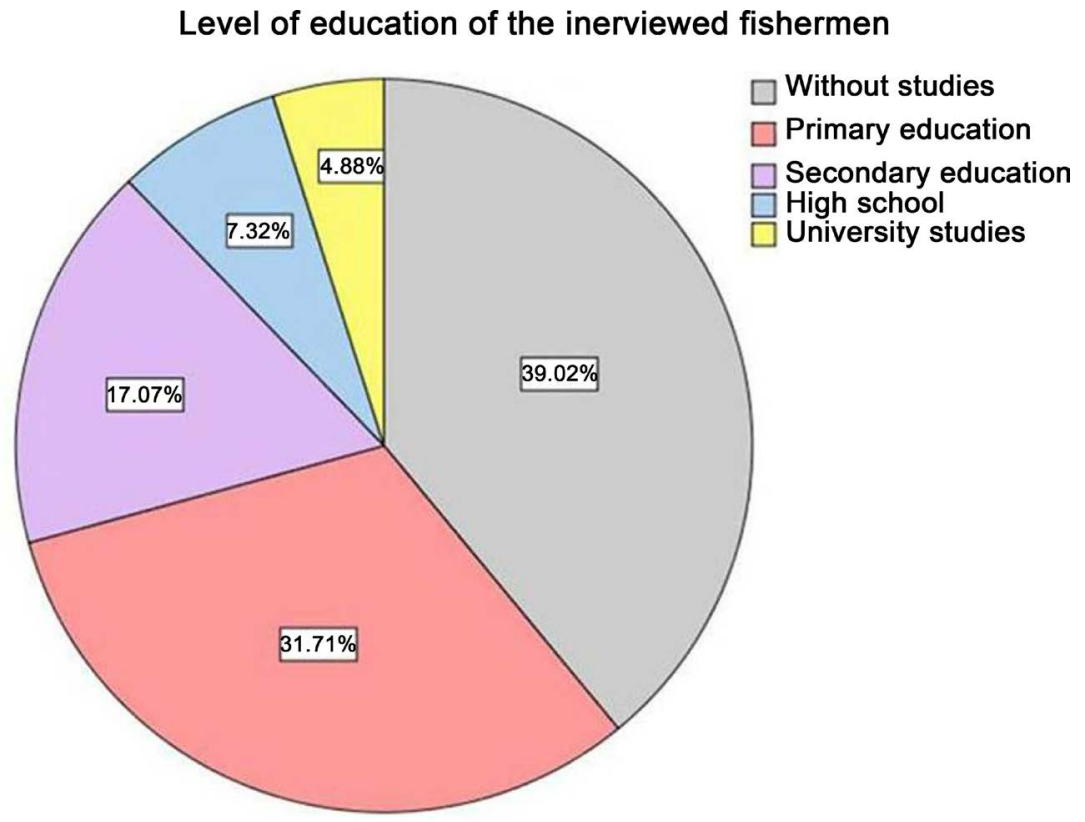

Figure 2. Graph on school levels education in fishermen of the Costa Chica, Guerrero.

metal levers, spatulas and gloves for mollusc fishing and two fishing production cooperative societies operating a $5 \mathrm{hp}$ compressor (regulator, hoses, weights belt and neoprene suits) were located. The fleet registered in the seven cooperatives of the Costa Chica was 18 boats total authorized for fishing. The fishermen mention that each boat transports four fishermen. It was calculated that on average the fishermen work 4.3 days a week, which gives us an average of 224.21 days worked per year.87.51\% of the fishermen interviewed reported that they apply some type of management plan for the conservation of some of the species they catch. They also apply some type of management plan to the sites where they capture. The fishermen of the cooperatives make their own closures and closures declared by the SAGARPA. These closures are mainly focused on rock oysters. On the other hand, the interviews indicate that the fishermen have not received information on the implementation of any management plan for other mollusc species that they exploit. They have no information that biological-fishing studies have been carried out. The same fishermen, when surveyed, mentioned that due to the high market value of some species, their fishing was intense and uncontrolled, and that there is currently a decrease in the abundances and average sizes of the captured populations. Most of the mollusc species that they capture are not subject to any type of surveillance or control, so their extraction, despite their low abundances, remains intense.

\subsection{Income from Fishing}

The fishermen have their economic income as exclusive product of the mollusk they fish, worth $\$ 1806.00$ Mexican pesos per week. Each fisherman spends $\$ 100.00$ pesos per exit per boat to purchase fuel and lubricants.

Fishing cooperatives in the Costa Chica market their product mainly at the 
landing sites. The main buyers of mollusc fishing are the owners of restaurants and local inhabitants. It is worth mentioning that the most important landing sites are located in Playa Ventura, municipality of Copala, La Bocana beach, municipality of Marquelia and El Faro, municipality of Cuajinicuilapa.

Rock oyster (Striostrea prismatica) constitutes the most profitable fishery by the volumes of capture and the price of the product, followed by three snails: Hexaplex princeps, $H$. radix and $H$. regius

The species with the highest sale value are larger mollusks sold by piece or by shell, such as the snail Machachan (Lobatus peruvianus, and L. galeatus) with an approximate price of $\$ 116.25$, the snail chireta (Triplofusus princeps) with a unit price of $\$ 255.00$ and the callo de margarita clam (Spondylus limbatus) with a value of $\$ 100.00$ Mexican pesos, according to the information provided by the interviewees, these mollusks have low abundances and some of them are caught by request or for personal-consumption (Table 1).

\subsection{Mollusks Species Caught by Coastal Fisheries}

There were 25 species of molluscs with economic importance captured by coastal fisheries in Costa Chica. We identified 9 species of the Gastropoda Class, 14 species of the Bivalvia Class and 2 species of the Polyplacophora Class (Table 2).

Six species were the main subjects for capture. The populations of these species are the most abundant and/or those with the greatest economic reward to the fishermen: (Striostrea prismatica, Hexaplex princeps, H. radix, H. regius, Lobatus galeatus and Triplofusus prínceps) (Figure 3). Of all the species that are the main objective of capture, only the Striostrea prismatica has regulations implemented by SAGARPA to control their exploitation, in addition to this, there

Table 1. Costs and fishing season during the year by species in Costa Chica, Guerrero.

\begin{tabular}{|c|c|c|c|}
\hline Species & Name common & Costs for dozen or piece & Fishing season \\
\hline Lobatus peruvianus & Machachan & $\$ 116.25$ (piece) & 12 months \\
\hline Malea ringens & Calavera & $\$ 255$ (piece) & 12 months \\
\hline Hexaplex regius & Chino & $\$ 58.18$ & 12 months \\
\hline Hexaplex radix & Chino & $\$ 57.37$ & 12 months \\
\hline Hexaplex princeps & Chino & $\$ 56.17$ & 12 months \\
\hline Triplofusus princeps & Chireta & $\$ 100$ (piece) & 12 months \\
\hline Modiolus capax & Mejillón de mar & $\$ 28.33$ & 12 months \\
\hline Pinctada mazatlanica & Madre perla & $\$ 180.33$ & 12 months \\
\hline Atrina maura & Callo de hacha & $\$ 45$ & 12 months \\
\hline Striostrea prismatica & Ostión de roca & $\$ 55$ & 9 months \\
\hline Spondylus limbatus & Callo de margarita & $\$ 118.33$ (piece) & 12 months \\
\hline Periglypta multicostata & Reina & $\$ 244.38$ & 12 months \\
\hline Chiton articulatus & Cucaracha de mar & $\$ 29$ & 12 months \\
\hline
\end{tabular}


Table 2. Cast of mollusc species of coastal fishing in Costa Chica, Guerrero.

\begin{tabular}{|c|c|}
\hline Family, genus and species & Name common \\
\hline \multicolumn{2}{|l|}{ STROMBIDAE } \\
\hline \multicolumn{2}{|l|}{ Lobatus peruvianus Swainson, 1823} \\
\hline \multicolumn{2}{|l|}{ Lobatus galeatus Swainson, 1823} \\
\hline \multicolumn{2}{|l|}{ TONNIDAE } \\
\hline Malea ringens (Swainson, 1823) & Calavera \\
\hline \multicolumn{2}{|l|}{ MURICIDAE } \\
\hline \multicolumn{2}{|l|}{ Hexaplex regius (Swainson, 1821) } \\
\hline Hexaplex radix (Gmelin, 1791) & Chino \\
\hline \multicolumn{2}{|l|}{ Hexaplex princeps (Broderip, 1833) } \\
\hline Neorapana muricata (Broderip, 1832) & Mamey \\
\hline \multicolumn{2}{|l|}{ FASCIOLARIIDAE } \\
\hline Triplofusus princeps (G.B. Sowerby I, 1825) & Chireta \\
\hline \multicolumn{2}{|l|}{ VASIDAE } \\
\hline Vasum caestus (Broderip, 1833) & Madera \\
\hline \multicolumn{2}{|l|}{ MYTILIDAE } \\
\hline Modiolus capax (Conrad, 1837) & Mejillón de mar \\
\hline \multicolumn{2}{|l|}{ PTERIIDAE } \\
\hline Pinctada mazatlanica (Hanley, 1856) & Madre perla \\
\hline \multicolumn{2}{|l|}{ PINNIDAE } \\
\hline Atrina maura (Sowerby, 1835) & Callo de margarita \\
\hline \multicolumn{2}{|l|}{ OSTREIDAE } \\
\hline Striostrea prismatica (Gray, 1825) & Ostión de roca \\
\hline \multicolumn{2}{|l|}{ SPONDYLIDAE } \\
\hline Spondylus limbatus G.B. Sowerby II, 1847 & Callo de margarita \\
\hline \multicolumn{2}{|l|}{ CHAMIDAE } \\
\hline Chama coralloides (Olsson, 1971) & Ostión violeta \\
\hline Chama echinata (Broderip, 1835) & \\
\hline \multicolumn{2}{|l|}{ Chama mexicana (Carpenter, 1857) } \\
\hline \multicolumn{2}{|l|}{ VENERIDAE } \\
\hline Periglypta multicostata (Sowerby, 1835) & Reina \\
\hline Megapitaria squalida (G.B. Sowerby I, 1835) & \\
\hline \multicolumn{2}{|l|}{ Megapitaria aurantiaca (G.B. Sowerby I, 1835) } \\
\hline \multicolumn{2}{|l|}{ DONACIDAE } \\
\hline \multicolumn{2}{|l|}{ Donax kindermanni (Philippi, 1847) } \\
\hline Donax caelatus Carpenter, 1857 & Almejas \\
\hline \multicolumn{2}{|l|}{ Donax punctatostriatus Hanley, 1843} \\
\hline \multicolumn{2}{|l|}{ CHITONIDAE } \\
\hline \multicolumn{2}{|l|}{ Chiton articulatus Sowerby in Broderip Sowerby, 1832} \\
\hline CHAETOPLEURIDAE & Cucaracha de mar \\
\hline Chaetopleura lurida (Sowerby, 1832) & \\
\hline
\end{tabular}




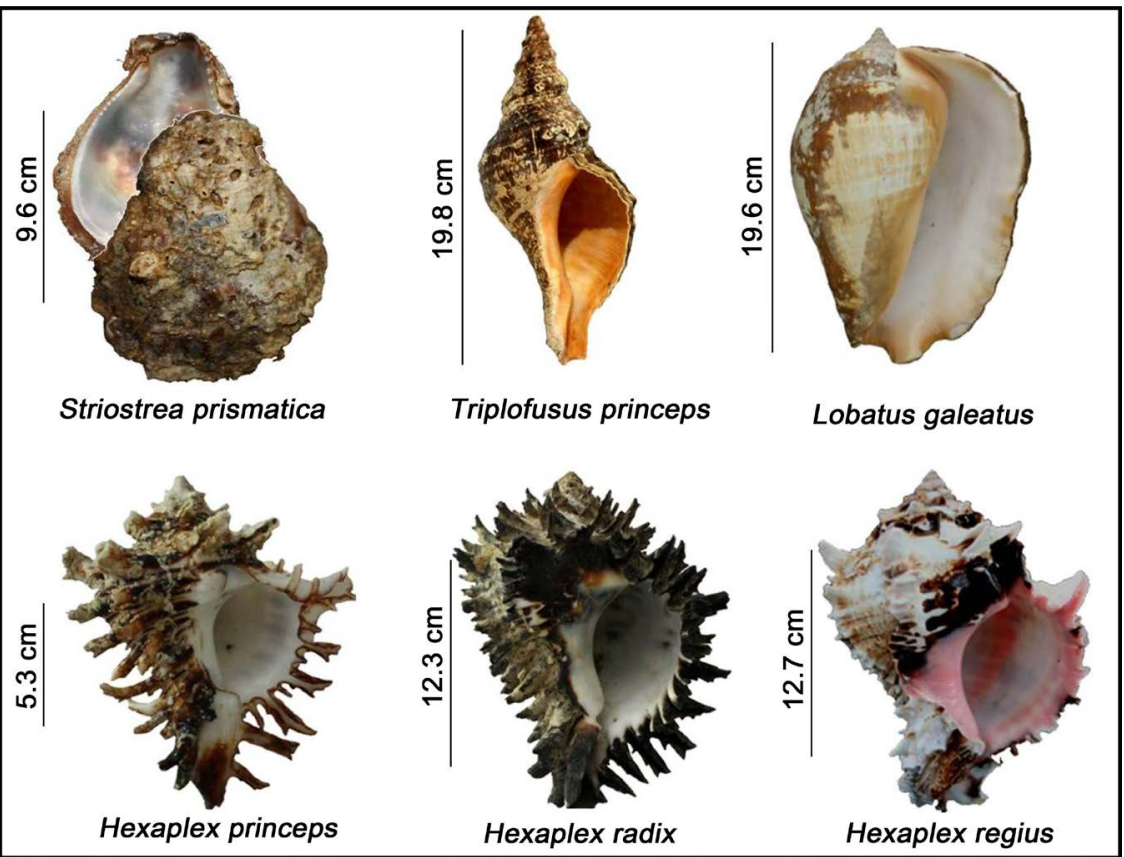

Photography: Lizeth Galeana-Rebolledo.

Figure 3. Cast of mollusc species of coastal fishing in Costa Chica, Guerrero.

is a rotation in the operation at the banks agreed upon by the fishermen independently of the instructions of SAGARPA in order to protect the resource. The rest of the species are captured without any control or surveillance.

\section{Discussion}

\subsection{Socioeconomic Characteristics of Fishermen Who Are Members of Fishing Cooperatives in the Costa Chica Region}

According to the data provided by SAGARPA, there are 166 fishermen affiliated with the fishing cooperatives that carry out extractive activity of marine mollusks in the Costa Chica, while in Acapulco, according to the data of [3], $301 \mathrm{fi}$ shermen are dedicated to mollusks fishing in the Acapulco region. The above data indicate that the intensity of fishing in the Costa Chica is much lower than in Acapulco. For each fisherman authorized to fish for marine mollusks in the Costa Chica region there are 1.81 authorized fishermen in Acapulco, in addition, the Costa Chica region has an area of $180 \mathrm{~km}$ of coastline, while the Acapulco region has a coastline of $62 \mathrm{~km}$.

The majority of shellfish fishermen in Acapulco are dedicated exclusively to this activity (87\%) and most of them are born in Acapulco [1].

For the region of the Costa Chica the same situation occurs, most of their main labor activity is fishing and the fishermen are natives of the municipalities that make up the Costa Chica region.

With respect to the age of the fishermen, [1] stated that for Acapulco most fishermen are over 55 years old. The present study reports for the Costa Chica, there are adult replacements by young people, since $51 \%$ of fishermen are be- 
tween 22 and 39 years old.

In relation to the level of schooling education, [1] concluded that most of the fishermen interviewed in Acapulco have completed primary or secondary education. [2] referred to the fishermen of Costa Chica that $75 \%$ have not finished and only $22 \%$ have completed primary education, they say that the level of school education among fishermen in the region of the Costa Chica is minimal. However, in the present study, five years later, it was found that the percentage of those who have unfinished primary education is much lower, 39\%, and the percentage with complete primary and secondary education increased significantly. There were also fishermen who have university studies.

In relation to years of work experience, for Acapulco [1] indicates that most fishermen have between 20 and 30 years of experience as fisherman and as cooperative associates. The present study found that the experience as a fisherman and as a member is very heterogeneous, mainly due to the replacement of adults by young people e member.

For Costa Chica, [2] indicated that on average a fisherman receives about $\$ 858$ pesos per week. For Acapulco, [1] reports a weekly income of $\$ 908.33$ pesos exclusively from fishing. The present study found for the fishermen of Costa Chica a weekly income of $\$ 1806$ pesos exclusively from fishing. In the Costa Chica revenue one can still find more abundant populations and larger average size and therefore is more economically profitable. Hence a large replacement of adult fishermen by young people with a higher level of schooling is observed given that the income from carrying on fishing activity is attractive, especially in places where labor options are scarce. The replacement of adult fishermen by young people is a very restricted phenomenon in Acapulco. According to the information provided by [2], in Acapulco there are several labor options with a higher payment than what can be obtained as a fisherman.

Commercialization, [2] pointed out that the main market is Acapulco followed by Chilpancingo. [5] indicated that the greatest commercial seafood demand for the State of Guerrero is concentrated in Ixtapa-Zihuatanejo and Acapulco. [2] mentioned that Acapulco is the main center of trade, not only of seafood products but of a large part of the goods that make up the regional exchange of both coasts of Guerrero. The present study indicates that fisheries commercialization in Costa Chica, Guerrero, follows a traditional pattern in which fishermen land their on beaches, separated from each other by considerable distances; In general the landings are of low volume, which implies significant expenses at the time of their movement and transfers to other places, however, Acapulco is the main center for trade of marine mollusk from the Costa Chica fishing.

[1] refers that in Acapulco the most profitable fisheries in economic value are: Spondylus limbatus, Periglypta multicostata, Megapitaria squalida and Anadara formosa, and all these species have an average cost per dozen of $\$ 120$ pesos. [4] reports the rock oyster Crassostrea iridescens (Striostrea prismatica) with a high economic value. [2] mentioned that species of fish and rock oyster Crassostrea 
prismatica (Striostrea prismatica) constitute $80 \%$ of the regional catch in Costa Chica, which reveals the existence of fishing activity that develops under the multispecies context. [5] reported that along the coast of Guerrero there are 35 dry docks, places where mainly marine scale fish is landed, followed by sharks, snail, octopus, oyster, sea cockroach, callo de hacha clam. With regard to mollusks, the resource of greatest commercial importance in volume and commercial value corresponds to the oyster Crassostrea spp. (Striostrea prismatic) that is extracted along the entire coast of Guerrero. The present study indicates that the most profitable fisheries for fishermen in the Costa Chica is the Striostrea prismatica rock oyster fishery, followed by the Chinese snails Hexaplex princeps, $H$. radix and $H$. regius

\subsection{Cohort to Mollusk Species with Commercial Importance}

Few studies talk about the cohort of mollusk species that are used for human consumption in the State of Guerrero, among them [5] for Guerrero, [1] [3] and

[12] for the municipality of Acapulco. These works have reported a total of 56 species for the coasts of the State of Guerrero. The present study found 22 of the 56 species that had already been reported in the aforementioned works (Hexaplex regius, $H$. radix, $H$. princeps, Neoropana muricata, Vasum caestus, Lobatus galeatus, L. peruvianus, Triplofusus princeps, Malea ringens, Modiolus capax, Pinctada mazatlanica, Atrina maura, Pinna rugosa, Striostrea prismatic, Spondylus limbatus, Chama coralloides, C. echinata, C. mexicana, Periglypta multicostata, Megapitaria aurantiaca, M. squalida and Chiton articulatus). However, the clams Donax kindermani, D. caelatus, D. punctactostratus and the sea cockroach Chaetopleura lurida are also reported. These species have not been previously reported as having commercial importance for the State of Guerrero. [3] found 48 species of mollusks that are fished in Acapulco for human consumption and the present study presents 25 species. The difference in the number of species reported by both studies can be explained according to the aforementioned authors, who state that the demand in Acapulco to satisfy the market for human consumption is very high, mollusks are under pressure by fishing and are consumed not only by the local population but also by a large number of tourists and due to the intensity of fishing and the lack of regulatory mechanisms, fishermen catch other species to meet the demand and obtain income that allows them to survive, hence they report species that are not used as a commercial product in other parts of the Mexican Pacific.

\section{Conclusions}

Mollusk fishing at Costa Chica region allows fishermen to have acceptable income to cover basic individual and family needs. For the mollusk fishery to be still profitable in the region, the present study highlights two elements that significantly influence this situation. First the intensity of fishing in the region is much lower than what occurs in other regions such as Acapulco, so the product 
is of better quality and more abundant, and second is in the increment on schooling, which allows them to have greater knowledge in the administration of their resources and better organization of fish coop units.

On the other hand, given that income from work as a fisherman allows for basic needs met, this activity is attractive for young people, who replace adults by occupying the spaces they leave in the work environment. The fishermen of the region have the rock oyster as one of the most profitable fisheries, so this resource has territorial limitation and rotation of banks for their capture by fish coop units, however, other mollusk species in the Costa Chica continue without being subject to some kind of surveillance, so that their extractions despite their low abundances are maintained intensively. In the list of species that are currently captured for human consumption reported by this study, there are species that are registered in the Official Mexican Standard NOM-059-SEMARNAT-2010 [13] and are subject to special protection, such as Pinctada mazatlanica and Spondylus limbatus.

Due to the low abundances and sizes in some populations of mollusks, the fisheries in the Costa Chica have diverged, increasing the list of species in the region. Such species are used for human consumption, ornaments, and handicrafts. It is worth mentioning that these species are of small sizes such as the clams of the Donax spp and Chaetopleura lurida.

The overfishing of some mollusks of Costa Chica is affecting the sustainability of the resources and urgently requires fisheries and biological evaluations of the species that are being captured to determine catch volumes, record first sexual maturity sizes, and minimum capture sizes.

For responsible and sustainable fishing to flourish, greater participations of government agencies, as well as civil society and private sector are required, so help is needed to find technologies and solutions that can be applied to this problem [1]. Also, there is need to invest in technical and scientific research, which generate ecological information reproductive cycles and biology of all the species that are information, we will have the possibility to improve the fisheries' management and project the resource towards a sustainable management.

\section{Acknowledgements}

To the National Council of Science and Technology for the support with a postgraduate scholarship for the first author of this writing. This work was partially financed by the UAGro in 2013 convocation with the project analysis of the situation of the coastal fishing of molluscs in the Costa Chica of Guerrero. Also to the fishermen affiliated to the Cooperative Fishing Production Societies of the Costa Chica for providing the facilities and information for this research to be carried out.

\section{References}

[1] Castro-Mondragon, H., Flores-Garza, R., Rosas-Acevedo, J.L., Flores-Rodríguez, R., García-Ibáñez, S. and Valdez-González, A. (2015) Escenarios biológicos pesqueros y 
socioeconómicos de la pesca ribereña de moluscos en Acapulco. Revista Iberoamericana de Ciencias, 2, 9-23.

[2] Villerías, S.S. and Sánchez A.C. (2010) Perspectiva territorial de la pesca en la Costa Chica de Guerrero. Investigaciones Geográficas, Boleín del Instituri de Geografía, UNAM, 43-56.

[3] Castro-Mondragón, H., Flores-Garza, R., Valdez-González, A., Flores-Rodríguez, P., García-Ibáñez, S. and Rosas-Acevedo, J.L. (2016) Diversidad, especies de mayor importancia y composición de tallas de los moluscos en la pesca ribereña en Acapulco, Guerrero, México. Acta Universitaria, 26, 24-34.

[4] Villerías, S. Tello, A.P.V. and Rondín, G.J. (2014) Puerto Vicente Guerrero, México: La pesca ribereña, características sociales y económicas. Revista Tlamati Sabiduría, 5, 48-52.

[5] Gutiérrez, Z.R.M. and Cabrera, M.E. (2012) La pesca ribereña de Guerrero. 1st Edition, Instituto Nacional de la Pesca, México.

[6] Instituto Nacional de Estadística y Geografía (2010) Anuarios estadísticos del Estado de Guerrero, México.

[7] Keen, A.M. (1971) Sea Shells of Tropical West America. Stanford University Press, California, Stanford.

[8] Kaas, P. and Van Belle, R.A. (1987) Suborder Ischnochitonina. Ischnochitonidae: Chaetopleurinae y Ischnochitoninae (pars). Additions to Vols 1 y 2. Brill Academic Publishers, Leiden, The Nertherlands.

[9] Kaas, P., Van Belle, R. and Strack, L.H. (2006) Monograph of Living Chitons (Mollusca: Polyplacophora): Volumen 6, Family Schizochitonidae. Brill Academic Publishers, Leiden, The Nertherlands

[10] Coan, E.V. and Valentich-Scott, P. (2012) Bivalve Seashells of Tropical West America. Marine Bivalve Mollusks from Baja California to Peru. Santa Barbara Museum of Natural History, Santa Barbara, California.

[11] World Register of Marine Species (2016) Registro mundial de especies marinas. http://www.marinespecies.org

[12] Flores-Garza, R., García-Ibáñez, S., Flores-Rodríguez, P., Torreblanca-Ramírez, C., Galeana-Rebolledo, L., Valdés-González, A., Suastegui-Zárate, A. and Violante-González, J. (2012) Commercially Important Marine Mollusks for Human Consumption in Acapulco, México. Natural Resources, 3, 11-17. https://doi.org/10.4236/nr.2012.31003

[13] Norma Official Mexicana (2010) NOM-059-SEMARNAT-2010. Protección ambiental-Especies nativas de México de flora y fauna silvestres-Categorías de riesgo y especificaciones para su inclusión, exclusión o cambio-Lista de especies en riesgo. Versión electronic, Segunda Sección 1. 